\title{
Table of notes
}

\begin{tabular}{|l|l|l|}
\hline \multicolumn{1}{|c|}{ Notes } & \multicolumn{1}{|c|}{ Old text } & New text \\
\hline $\begin{array}{l}\text { Plots, as well as overall presentation } \\
\text { could be improved to enhance clarity } \\
\text { as well as indicators of the statistical } \\
\text { accuracy of the numerical results } \\
\text { (confidence intervals, etc.). }\end{array}$ & $\begin{array}{l}\text { P.9, col.1,3d paragraph from the } \\
\text { top: } \\
\text { parameters, the experiments were } \\
\text { conducted 10 times, and then we } \\
\text { calculated the average value. }\end{array}$ & $\begin{array}{l}\text { For each combination of the problem } \\
\text { parameters, the experiments were } \\
\text { conducted 10 times, and then we } \\
\text { calculated the average value. At the } \\
\text { same time the dispersion of values in } \\
\text { statistical selection did not exceed } \\
10 \text { percent. }\end{array}$ \\
\hline
\end{tabular}

